\title{
Trends of Livability in the Capital Region of Taiwan
}

\author{
Wei-Yi Li*1 ${ }^{1}$ and Chia-Chi Yao ${ }^{2}$
}

${ }^{1}$ Associate Professor, Department of Architecture, National Taiwan University of Science and Technology, Taiwan
${ }^{2}$ Ph.D. Candidate, Department of Architecture, National Taiwan University of Science and Technology, Taiwan

\begin{abstract}
Although Taipei and New Taipei together constitute the largest metropolitan area of Taiwan, studies have indicated that they are classified into 2 different categories of livability regarding urban development. Taipei is the most developed and livable city in Taiwan; although the adjacent New Taipei suburb is not as urbanized or livable, it is steadily improving. Frequently viewed as an extension of Taipei, New Taipei is actually distinct in various aspects and has its own developmental trajectory. These 2 municipalities provide differing livability conditions; thus, with integration, the overlapping and complementary nature of the services provided by Taipei and New Taipei can enable the expansion of the metropolitan service area to a greater urban scale, resulting in an aggregation effect. Without integration, the varying livability conditions will still allow the 2 municipalities to become highly complementary and mutually dependent cities. However, both municipalities face challenges, such as significantly low population growth, and negative consequences associated with a high degree of urbanization, including low birth rates, insufficient public areas, lagged urban planning, and the lack of a coherent vision. These issues must be addressed in the future development of the capital region of Taiwan to efficiently improve livability and community welfare.
\end{abstract}

Keywords: categories of livability; multivariate analysis of variance; capital region; livability indicators; Taiwan

\section{Introduction}

Situated at the northern tip of Taiwan, Taipei and the surrounding New Taipei region (formerly called Taipei County) constitute only $6.5 \%$ of the total area, of Taiwan, but approximately $28 \%$ of the population. Taipei has been the capital of the Republic of China since 1949 , and is not only the seat of government, but also the center of economic and commercial activity in Taiwan. Taipei is completely surrounded by New Taipei, which is a municipality that also has a substantial population and extensive economic activity, although New Taipei is frequently viewed as an extension of Taipei. Together these two municipalities constitute the most vital metropolitan area in Taiwan.

Taipei has historically had the most developed infrastructure in Taiwan, and policy makers regularly propose various plans and development goals intended to enhance the standard of living and the sustainability of the capital region. In 2010, Taipei hosted the Taipei International Flora Exhibition, and is currently competing for the designation of the

*Contact Author: Wei-Yi Li, Associate Professor,

Department of Architecture, National Taiwan University of Science and Technology, 43 Keelung Rd., Section 4,

Taipei, 106, Taiwan (R.O.C.)

Tel: +886-2-2737-6722 Fax: +886-2-2737-6721

E-mail: 1wi@mail.ntust.edu.tw

(Received October 9, 2012 ; accepted July 23, 2013)
2016 World Design Capital. Such endeavors not only boost the tourism industry and promote international investment, but also enhance the overall profile of the city. New Taipei is also focusing on improving its basic infrastructure. One example is the plan to add three lines to the existing mass rapid transit (MRT) network. New Taipei is also promoting the preservation and renovation of cultural heritage sites as a strategy to promote tourism and provide venues for community activities. Examples include the Wulai Cherry Blossom Festival, the Pingxi Sky Lantern Festival, and the historic sites of Sanxia, Danshui, and Jinshan. Such projects do not require large budgets to generate substantial economic activity. In addition to preserving cultural and natural resources, such projects provide an immediate stimulus to all levels of the local service industry.

In 2010, Taiwan amended the Local Government Act by increasing the number of special municipalities across Taiwan to five. Of the three new special municipalities officially organized on December 25, 2010, one is New Taipei; the other two are Taichung City, created by integrating Taichung and Taichung County, and Tainan City, created by integrating Tainan and Tainan County. The creation of these special municipalities was based on central place theory, in which surrounding urban areas are organized and urban service areas are expanded through geographical integration policies, thereby achieving a city diffusion effect. In other words, the amendment aimed to 
redistribute the economic activities in the northern, central, and southern regions of Taiwan to resolve related problems of uneven distribution.

In this study, the capital region is defined as consisting of Taipei and New Taipei, the two cities in Taiwan with the greatest degree of urbanization, highest population density, and the most robust commercial, economic, and political activity. Should the two special municipalities develop independently, or should they be geographically integrated to achieve joint development? Which approach is the most suitable for urban development in Taiwan as it becomes a developed country? To answer these questions, we examine differences in the urban development of the two cities (New Taipei and Taipei), their degrees of livability, and whether they can attract a greater population to drive regional development. The purposes of this research are to determine the main factors that have a bearing on livability in the capital region, how they are changing, and future possibilities for development.

\section{Literature Review}

Yuan (2005) indicated that livable cities are cities that exhibit coordinated economic, social, cultural, and environmental development, as well as a favorable living environment capable of satisfying the physical and psychological needs of its inhabitants as a city suitable for human work, life, and residence. "Livability is the most basic demand people have of livable cities, that is, the ability of a city to make its residents feel safe, comfortable, and relaxed." E. Salzano (1997) believed that livable cities are hubs connecting the past and the future as cities capable of sustaining further development. Therefore, livability is a concept of sustainable development for society and individual persons.

In contrast to Chen and Lin (2010), this study uses the Fuzzy Delphi Method (FDM) and analytical hierarchy process (AHP) to construct a two-stage qualitative analysis model and to create a method for evaluating livable city index weights for Taiwanese cities. This study applies econometric analysis to evaluate city livability based on quantifiable indicators, such as city area, public facilities, software, hardware (infrastructure), and quantity. The purpose of this approach is to use quantifiable numerical indicators for various years to objectively evaluate variations in the livability categories of Taiwanese cities and compare the variation trends for livability conditions of Taipei and New Taipei.

Prior to the amendments to the Local Government Act which took effect in December 2010, Taiwan had 25 cities and counties. Li and Yao (2010) used a quantitative index consisting of 32 indicators compiled in 2007 to measure and compare the livability of the 23 cities and counties in Taiwan with a population of at least 100,000. Multivariate factor analysis was applied to the values of the index to group the key factors into seven clusters. Cluster analysis was then used to determine the four main categories of livability. These categories were compared using Analysis of Variance (ANOVA) and Scheffe's post hoc comparison, and were named according to the results (Fig.1. and Table 1.).

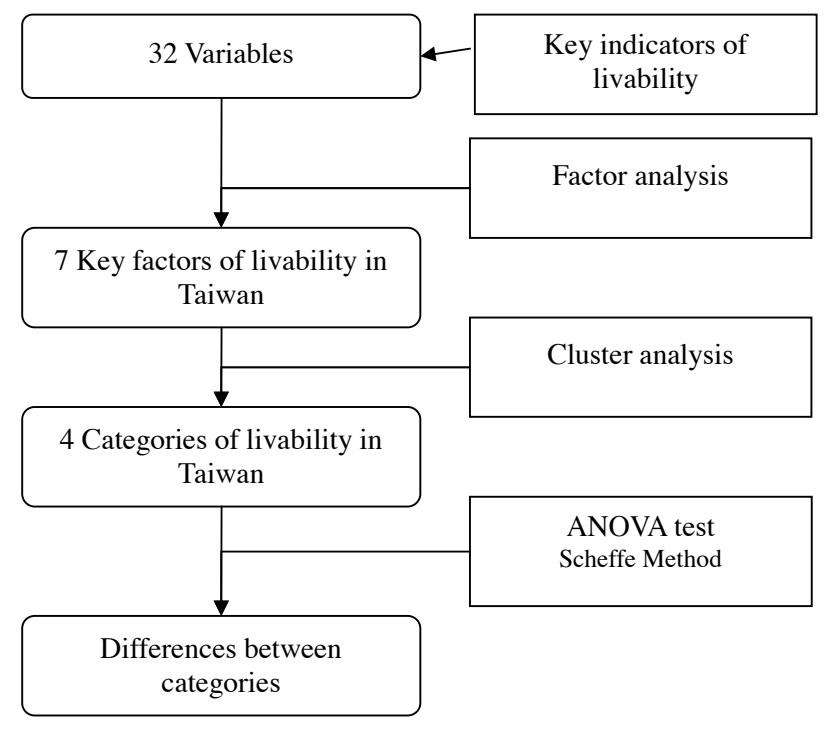

Fig.1. Analytical Flow Chart of Li and Yao (2010)

Table 1. Variance Between the Categories of Livability of Li and Yao (2010)

\begin{tabular}{|c|c|c|c|c|c|c|}
\hline \multirow{2}{*}{ Mean } & \multicolumn{4}{|c|}{ Category } & \multirow[t]{2}{*}{ F Value } & \multirow{2}{*}{$\begin{array}{l}\text { Scheffe's } \\
\text { Method }\end{array}$} \\
\hline & 1 & 2 & 3 & 4 & & \\
\hline Overall Development & -0.062 & 0.613 & 0.246 & -0.894 & 2.702 & $2>4$ \\
\hline Advanced Infrastructure & -0.527 & -0.539 & 0.913 & 0.471 & 4.356 & $3>2$ \\
\hline Health Care & 0.068 & -0.003 & 0.042 & 0.190 & 0.198 & $4>2$ \\
\hline Housing Standards & 1.047 & -0.455 & -0.268 & -0.652 & 6.815 & $1>4$ \\
\hline Purchasing Capacity & -0.441 & 0.102 & 0.246 & 0.249 & 0.646 & $4>1$ \\
\hline Job Availability & -0.241 & 0.744 & -1.314 & 0.759 & 14.263 & $4>3$ \\
\hline Health & 0.248 & -0.674 & -0.222 & 0.683 & 2.237 & $4>2$ \\
\hline \multirow[t]{2}{*}{ Designation } & Basic & Competitive & Conflicting & Slow & & \\
\hline & Satisfaction & Development & Development & Development & & \\
\hline \multirow{7}{*}{ Cities and Counties } & Taipei City & Keelung City & Taoyuan County & Changhua & & \\
\hline & Hsinchu City & New Taipei City & Hsinchu County & County & & \\
\hline & Yilan County & Kaohsiung City & Taichung City & Yunlin County & & \\
\hline & Miaoli County & Tainan City & Taichung & Chiayi County & & \\
\hline & Penghu County & Chiayi City & County & Tainan County & & \\
\hline & Hualien County & Kaohsiung County & Nantou County & Pingtung & & \\
\hline & Taitung County & & & County & & \\
\hline
\end{tabular}


According to the results of the previous study by Li and Yao (2010), in 2007, the most desirable municipalities in which to live were those where the essential infrastructure was already satisfactory and the emphasis had shifted to other factors that could further enhance the overall quality of life. Labeled "Basic Satisfaction," in addition to Taipei, this category also included the three counties with the best natural environments: Hualien, Taitung, and Yilan. Although none of these counties has a high level of development, they do have abundant natural resources and robust tourism industries, indicating that livability in Taiwan is no longer a simple matter of urbanization or advanced infrastructure.

In this previous study, Taipei County was placed in the "Competitive Development" category, in which the greatest emphasis is placed on purchasing capacity and job availability. The municipalities in this category also stress infrastructure development, indicating that they are still inadequate in this respect.

In this study, we use the quantitative index consisting of 32 items developed by Li and Yao (2010) to examine and compare the changes in livability that have occurred over the past few years in the capital region.

\section{Research Design}

Of the 32 indicators used in the index by Li and Yao (2010), only 28 were representative in 2007 through a factor analysis (which is a type of multivariate analysis) to extract livability conditions. The results indicated that seven condition factors were the most suitable clusters for further analysis, with a cumulative explained variance of $87.425 \%$. Each cluster was named in accordance with the particular characteristics of the indicators included therein to clearly define overall development, advanced infrastructure, health care, housing standard, purchasing capacity, job availability, and health as the primary livability factors (Table 2.). Cluster analysis, ANOVA, and Scheffé's post hoc comparison were then used to categorize cities into four primary types: Basic Satisfaction, Competitive Development, Conflicting Development, and Slow Development (Tables 2. and 4.).

This study applied the 32 indicators used in the mentioned study to examine the indicator values of each city in 2009 to observe changes in the livability category and conditions of each city. A factor analysis was conducted to extract the livability conditions. The results of the study indicated that in the 2009 index, 25 indicators were representative, and the seven clusters again had a high level of significance, with a cumulative explained variance of $85.064 \%$. Each cluster was named in accordance with the particular characteristics of the indicators included therein: Convenience, Comfort, Housing, Safety, Construction and Development, Expenditures and Housing, and Food and Plumbing (Table 2.).

Table 2. Comparison of the Livability Indexes for 2007 and 2009

\begin{tabular}{|c|c|c|c|}
\hline \multicolumn{2}{|l|}{2007} & \multicolumn{2}{|l|}{2009} \\
\hline Cluster & Indicators & Cluster & Indicators \\
\hline Overall Development & $\begin{array}{l}\text { 1. Educational Level } \\
\text { 2. Electricity Consumption } \\
\text { 3. Indoor Telephones } \\
\text { 4. Non-farming Population } \\
\text { 5. Urban Area } \\
\text { 6. Home Computers } \\
\text { 7. Population }\end{array}$ & Convenience & $\begin{array}{l}\text { 1. Educational Level } \\
\text { 6. Home Computers } \\
\text { 8. Household Income } \\
\text { 2. Electricity Consumption } \\
\text { 9. Disposable Income } \\
\text { 10. Family Expenditures } \\
\text { 15. Print Media }\end{array}$ \\
\hline & $\begin{array}{l}\text { 8. Household Income } \\
\text { 9. Disposable Income } \\
\text { 10. Family Expenditures } \\
\text { 11.Sewage Disposal } \\
\text { 12. Housing Expenditures } \\
\text { 13.Traffic Accidents }\end{array}$ & & $\begin{array}{l}\text { 4. Non-farming Population } \\
\text { 3. Indoor Telephones } \\
\text { 11. Sewage Disposal } \\
\text { 13. Traffic Accidents }\end{array}$ \\
\hline Advanced Infrastructure & $\begin{array}{l}\text { 14. Crime Rate } \\
\text { 15. Print Media } \\
\text { 16. Heaters and Air Conditioners } \\
\text { 17. No. of TVs }\end{array}$ & Comfort & $\begin{array}{l}\text { 16. Heaters and Air Conditioners } \\
\text { 5. Urban Area }\end{array}$ \\
\hline Health Care & $\begin{array}{l}\text { 18. Western Doctors } \\
\text { 19. Correspondence Rate }\end{array}$ & Housing & $\begin{array}{l}\text { 12. Housing Expenditures } \\
\text { 17. No. of TVs }\end{array}$ \\
\hline Housing Standards & $\begin{array}{l}\text { 20. Home Ownership } \\
\text { 21. Indoor Plumbing } \\
\text { 22. Housing Construction }\end{array}$ & Safety & $\begin{array}{l}\text { 14. Crime Rate } \\
\text { 18. Western Doctors }\end{array}$ \\
\hline Purchasing Capacity & $\begin{array}{l}\text { 23. No. of Households } \\
\text { 24. Per Capita Expenditures }\end{array}$ & $\begin{array}{l}\text { Construction and } \\
\text { Development }\end{array}$ & $\begin{array}{l}\text { 22. Housing Construction } \\
\text { 30. Car Ownership } \\
\text { 31. Household Area }\end{array}$ \\
\hline Job Availability & $\begin{array}{l}\text { 25. Road Density } \\
\text { 26. Employment Rate }\end{array}$ & Expenditures and Housing & $\begin{array}{l}\text { 24. Per Capita Expenditures } \\
\text { 20. Home Ownership } \\
\text { 25. Road Density }\end{array}$ \\
\hline Health & $\begin{array}{l}\text { 27. Food Expenditures } \\
\text { 28. Garbage Collection }\end{array}$ & Food and Plumbing & $\begin{array}{l}\text { 27. Food Expenditures } \\
\text { 21. Indoor Plumbing }\end{array}$ \\
\hline
\end{tabular}


ANOVA and Scheffe's post hoc comparison were then applied to these seven clusters to generate the four categories of livability: Most Livable, Rapid Development, Leisure Economy, and Peripheral Change (Table 3. and Fig.2.). development in 2007 changed to leisure economy in 2009. Analysis of Categories 1 and 3 demonstrates a parallel process of steady development; one in the direction of increasingly sophisticated urban infrastructure, and one in the direction of promoting

Table 3. The Categories of Livability for 2007 and 2009

\begin{tabular}{|c|c|c|c|c|}
\hline Category & Basic Satisfaction & Competitive Development & $\begin{array}{l}\text { Conflicting } \\
\text { Development }\end{array}$ & Slow Development \\
\hline 2007 & $\begin{array}{l}\text { Taipei City } \\
\text { Hsinchu City } \\
\text { Yilan County } \\
\text { Miaoli County } \\
\text { Penghu County } \\
\text { Hualien County } \\
\text { Taitung County }\end{array}$ & $\begin{array}{l}\text { Keelung City } \\
\text { New Taipei City } \\
\text { Kaohsiung City } \\
\text { Tainan City } \\
\text { Chiayi City } \\
\text { Kaohsiung County }\end{array}$ & $\begin{array}{l}\text { Taoyuan County } \\
\text { Hsinchu County } \\
\text { Taichung City } \\
\text { Taichung County } \\
\text { Nantou County }\end{array}$ & $\begin{array}{l}\text { Changhua County } \\
\text { Yunlin County } \\
\text { Chiayi County } \\
\text { Tainan County } \\
\text { Pingtung County }\end{array}$ \\
\hline Category & Most Livable & Rapid Development & Leisure Economy & Peripheral Change \\
\hline 2009 & $\begin{array}{l}\text { Taipei City } \\
\text { Nantou County } \\
\text { Hualien County } \\
\text { Taitung County }\end{array}$ & $\begin{array}{l}\text { Keelung City } \\
\text { New Taipei City } \\
\text { Taoyuan County } \\
\text { Taichung City } \\
\text { Kaohsiung City } \\
\text { Tainan City } \\
\text { Chiayi City }\end{array}$ & $\begin{array}{l}\text { Hsinchu County } \\
\text { Hsinchu City } \\
\text { Yilan County } \\
\text { Penghu County }\end{array}$ & $\begin{array}{l}\text { Miaoli County } \\
\text { Taichung County } \\
\text { Changhua County } \\
\text { Yunlin County } \\
\text { Chiayi County } \\
\text { Tainan County } \\
\text { Pingtung County } \\
\text { Kaohsiung County }\end{array}$ \\
\hline
\end{tabular}

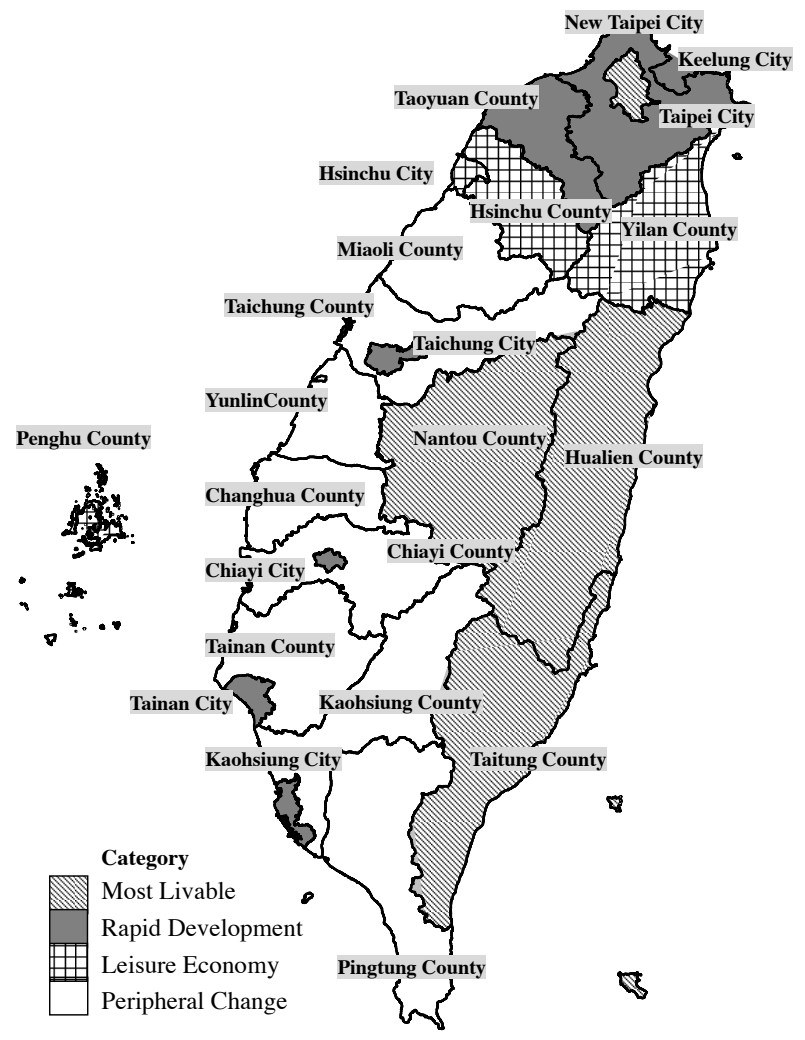

Fig.2. Four Categories of Livability

The results of the study indicated that, as in 2007, Taipei was again ranked highest in the most livable category. Similarly, Taipei County (New Taipei) was ranked second in the most livable category. However, numerous significant changes occurred in both of these categories (Fig.3.).

The most striking change in the 2009 index was the livability category change, in which conflicting an economy based on tourism and natural resources. Thus, the municipalities in both of these categories are becoming increasingly livable. Moreover, they satisfy the economic requirements of the people who live there, using different methods.

In addition to Taipei, the Most Livable category of the 2009 index also included several sparsely developed municipalities that were weak in advanced infrastructure but had robust tourism industries, the success of which is primarily the result of efforts by policy makers at both the local and central levels to promote tourism in these areas. The resulting influx of tourists, primarily from mainland China, has resulted in a major boost to these local economies, providing residents with local employment opportunities, and thereby stemming the historical trend of outward migration to cities and reducing the pace of urban sprawl.

The results of our study indicate that, as in New Taipei, the other municipalities that ranked in the second tier, Rapid Development, are either an integral part of the main city in the region, or else can be regarded as satellite cities. Because such municipalities are relatively undeveloped, they emphasize the development of essential infrastructure and public facilities; thus, the rapid expansion of New Taipei is mainly because it completely surrounds Taipei. For this reason, New Taipei, which is closely connected with Taipei, is the focus of this study in examining capital region urban development. Together, these two municipalities are essential in Taiwan for government, economics, and commerce.

Based on Li and Yao (2010), we examined the changes that have recently occurred in the livability indicators for the capital region and the related categories of livability, and examine possible future trends. 


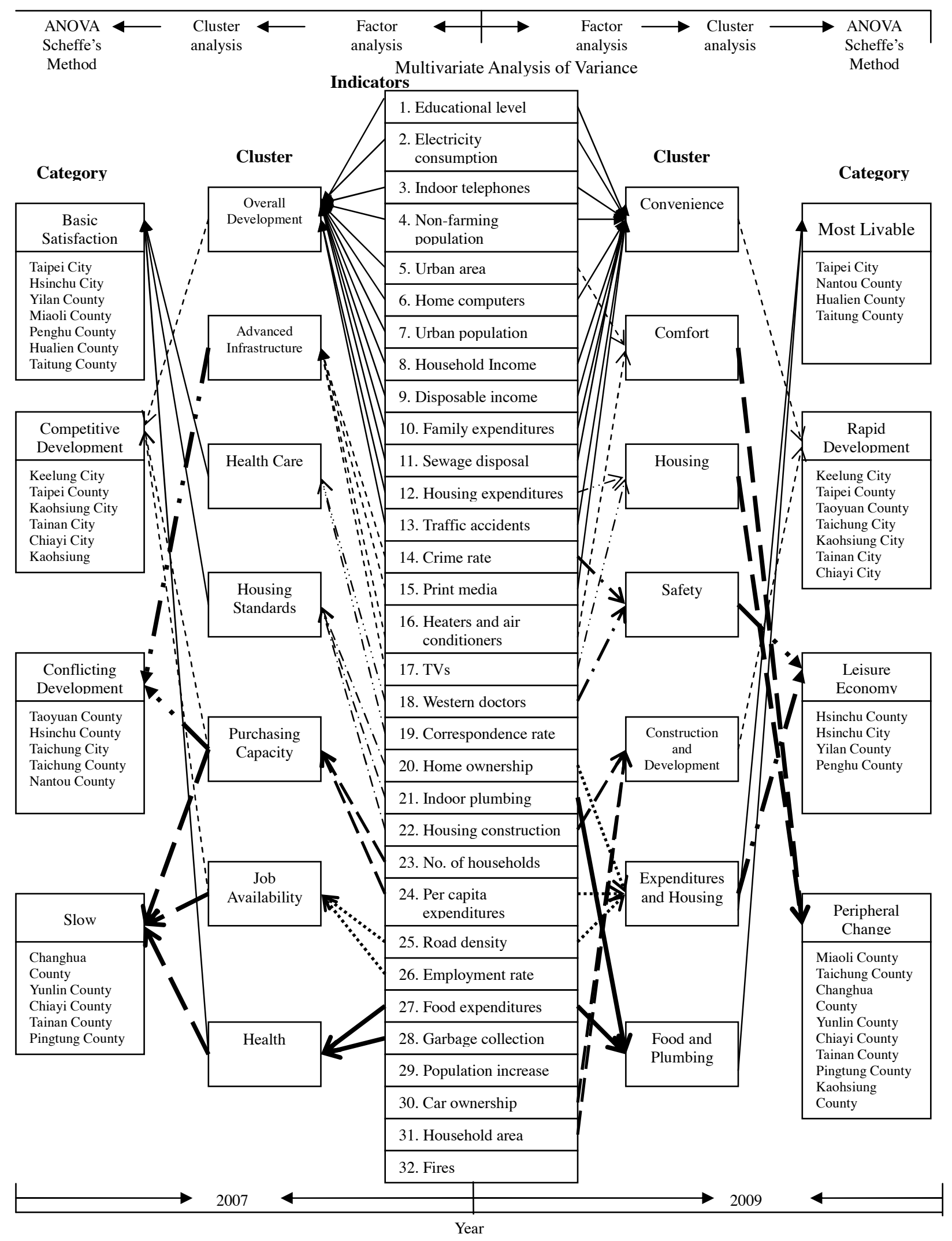

Fig.3. Categories and the Comparison

4. Changes in the Livability Categories of the Capital Region

4.1 New Taipei

Between 2007 and 2009, New Taipei experienced a major increase in the values contained within six indicators: construction, number of western doctors, number of TVs, per capita expenditures, household income, and home computers, indicating a steady increase in the direction of urbanization. In the case of construction, the significant increase in its value 
Table 4. Comparison of the Livability Indicators for New Taipei City (2007 and 2009)

\begin{tabular}{lll|lll}
\hline $\begin{array}{l}\text { Indicators which increased in } \\
\text { importance }\end{array}$ & 2007 & 2009 & $\begin{array}{l}\text { Indicators which decreased in } \\
\text { importance }\end{array}$ & 2007 & 2009 \\
\hline Construction & 13 & 19 & Population & 95 & 94.8 \\
Indoor Plumbing & 97.2 & 97.25 & Electricity Consumption & 2826 & 2825 \\
Road Density & 0.606 & 0.612 & Indoor Telephones & 65 & 62.54 \\
No. of Western Doctors & 9.5 & 10.3 & Car Ownership & 237.5 & 231.6 \\
Housing Expenditures & 17.5 & 21.3 & Correspondence Efficiency & 71.2 & 69 \\
Household Area & 31.88 & 32.16 & Home Ownership & 88.43 & 86.4 \\
Sewage Disposal & 61.53 & 72.49 & Garbage Collection & 0.64 & 0.58 \\
Educational Level & 65.7 & 67.7 & Crime Rate & 249.3 & 226.4 \\
No. of TVs & 494.3 & 523.9 & Traffic Accidents & 0.6 & 0.4 \\
Per Capita Expenditures & 18609 & 25192 & No. of Fires & 2.1 & 0.9 \\
Household Income & 1192907 & 1221746 & Print Media & 160.2 & 126.9 \\
Food Expenditures & 16.5 & 18 & Family Expenditures & 943345 & 938428 \\
Disposable Income & 930130 & 972062 & Heaters and Air Conditioners & 95.6 & 95.24 \\
Home Computers & 73.68 & 78.92 & Population Growth & 0.81 & 0.56 \\
Employment Rate & 45.5 & 46.7 & No. of Households & 2.94 & 2.86 \\
Non-farming Population & 96.8 & 97.2 & & & \\
\hline
\end{tabular}

can be viewed as the consequence of the continual efforts of local policy makers to promote major public construction projects, such as the three lines being added to the MRT network, a project that will greatly facilitate transportation between Taipei and New Taipei. A considerable increase also occurred in the road density indicator, and traffic congestion continues to be a major impediment to economic growth in the capital region. An increase was also noted in the number of western doctors.

During the same period, a decrease in the importance of population, population growth, and the number of households occurred, but housing expenditures experienced an increase in emphasis, indicating a steady increase in the amount of economic stress felt by residents because of an inadequate rise in income. However, an overall increase in the satisfaction with the overall quality of life is demonstrated by the concurrent reduction in concern paid to electricity consumption, car ownership, garbage collection, crime rate, and traffic accidents (Table 4.).

\subsection{Taipei}

In Taipei a major increase in emphasis is placed on the correspondence rate and sewage disposal, probably because of a major increase in commercial activity. It may also be consequent to the large influx of job seekers, leading city planners to place more priority on making improvements to the basic infrastructure. Moreover, the household income and disposable income in Taipei are considerably higher than elsewhere in Taiwan. In addition, the practices of promoting urban governance policies and hosting international activities indicate that Taipei is already highly developed.

Less stress was placed on electricity consumption, car ownership, garbage collection, and crime rate, indicating an increase in livability. Taipei has the lowest crime rate and the highest average level of

Table 5. Comparison of the Livability Indicators for Taipei City (2007 and 2009)

\begin{tabular}{|c|c|c|c|c|c|}
\hline $\begin{array}{l}\text { Indicators which increased in } \\
\text { importance }\end{array}$ & 2007 & 2009 & $\begin{array}{l}\text { Indicators which decreased in } \\
\text { importance }\end{array}$ & 2007 & 2009 \\
\hline Construction & 6.9 & 10.8 & Electricity Consumption & 2979 & 2945 \\
\hline Indoor Plumbing & 99.6 & 99.62 & Indoor Telephones & 90.14 & 85.72 \\
\hline Correspondence Efficiency & 525.3 & 586.9 & Car Ownership & 275.9 & 270.5 \\
\hline No. of Western Doctors & 28.2 & 29.9 & Garbage Collection & 0.55 & 0.42 \\
\hline Housing Expenditures & 20.9 & 26.8 & Crime Rate & 212.1 & 206.9 \\
\hline Household Area & 30.75 & 31.53 & No. of Fires & 1.4 & 1.2 \\
\hline Home Ownership & 81.02 & 82.34 & Print Media & 209.5 & 185.5 \\
\hline Sewage Disposal & 89.15 & 97.8 & Population Growth & 0.6 & -0.44 \\
\hline Educational Level & 83 & 84.5 & No. of Households & 2.8 & 2.74 \\
\hline No. of TVs & 549.8 & 572.7 & & & \\
\hline Per Capita Expenditures & 51515 & 56499 & & & \\
\hline Household Income & 1627979 & 1634790 & & & \\
\hline Family Expenditures & 1209167 & 1228826 & & & \\
\hline Food Expenditures & 15.8 & 16.4 & & & \\
\hline Disposable Income & 1262406 & 1271060 & & & \\
\hline Heaters and Air Conditioners & 93.96 & 93.99 & & & \\
\hline Home Computers & 78.38 & 80.71 & & & \\
\hline Employment Rate & 43.6 & 45 & & & \\
\hline Non-farming Population & 98.9 & 99 & & & \\
\hline
\end{tabular}


education in Taiwan; it is clear that Taipei is the most livable municipality on the island (Table 5.).

\subsection{Comparison of Taipei and New Taipei}

The indicators with more decreasing value in Taipei than in New Taipei were construction and crime rate; the indicators considered more significant in Taipei than in New Taipei were urban area, number of western doctors, indoor telephones, car ownership, housing expenditures, sewage disposal, educational level, per capita expenditures, per capita income, family expenditures, print media, number of TVs, and disposable income. This demonstrates that Taipei is much more livable than New Taipei.

These changes in the indicator values demonstrate a similarity in the developmental trends of Taipei and New Taipei. For example, a drop occurred in the indicator values in both municipalities for electricity consumption, indoor telephones, car ownership, garbage disposal, crime rate, number of fires, print media, population growth, and number of households. This indicates that New Taipei is in the process of attaining a higher level of development, similar to that of Taipei. However, population growth and the number of households dropped considerably more in Taipei than in New Taipei, although the average household income is higher in Taipei than it is in the rest of Taiwan. This is because Taipei is faced with a rapidly decreasing birth rate, a problem which is likely to have a negative impact on Taipei's future competitiveness. Although the birth rate is decreasing throughout Taiwan, the drop is especially acute in Taipei, largely because of the high cost of housing, which is the result of the high standard of living as well as governmental policies. In addition, economic opportunities in Taipei have not substantially increased, making it increasingly difficult to purchase a home. In such a situation, although Taipei is the most livable city in Taiwan, numerous residents barely benefit from its livability. This indicates that if livability is to become a reality for the majority of the residents of a city, it must necessarily include an increased income provided by greater economic opportunities.

New Taipei completely surrounds Taipei, and various people who cannot afford the high cost of housing in Taipei live in New Taipei and work in Taipei. For this reason, Taipei and New Taipei are determined to expand their common transportation facilities, especially the MRT system. However, as transportation between these two municipalities becomes more convenient, the cost of housing in New Taipei will increase accordingly; an inevitable result of urban sprawl. As Taipei and New Taipei become increasingly interconnected, the residents of New Taipei will have greater access to the economic opportunities in Taipei; however, this will also result in increased traffic congestion and housing costs.

The changes in the indicator values show that Taipei and New Taipei belong to two different categories of livability. For example, in Taipei, the value of correspondence efficiency increased; however, it decreased in New Taipei and throughout the rest of Taiwan. This is mainly owing to the increasing convenience of telephones and the Internet in Taiwan. One reason that correspondence efficiency is vital in Taipei is because Taipei is home to various temporary or short-term residents who come to Taipei to work or study, but have their permanent residence elsewhere. Another reason is that the high concentration of commercial and financial activity in Taipei creates an increased urgency for international mail, shipping, and advertising services. Another significant difference is that, in Taipei, the value of home ownership increased, but in New Taipei it decreased. This demonstrates that even as the gap between rich and poor widens, Taipei is still the destination of choice for those who can afford to live there, making it increasingly difficult for members of the middle class to buy a residence not only in Taipei, but also in New Taipei. This demonstrates how developments in Taipei have a definite effect on the livability in New Taipei.

Perhaps the main difference between these two municipalities is that New Taipei includes more rural areas. Moreover, within the borders of New Taipei are numerous regional administrative centers and trading areas. Once these areas become better connected by the planned mass transit projects, it is possible that many more residents of New Taipei will choose to work within their own municipality, thereby making New Taipei less dependent on Taipei.

\section{Conclusion}

This study examined and analyzed different city livability categories by using objective urbanization indicators. The results of this study indicated that Taipei exhibited optimal livability conditions in both 2007 and 2009; thus, Taipei is classified as a superior livability category, followed by New Taipei. In the future, if the two municipalities are not integrated to expand the urban area and related range of services, the two will provide different livability conditions. However, if the urban area can be expanded through integration, the complementary and similar degrees of urban development and livability, as well as geographical proximity, will create a significant agglomeration effect and will enable the sharing of resources.

Because of the longer period of urban development in Taipei, basic city infrastructure, such as sewage treatment and sewer facilities, is more comprehensive compared to other Taiwanese cities. The accumulation of a large population and commercial activity has led to optimal livability conditions in Taiwan and the highest proportion in income distribution. Taipei and New Taipei are bound in a relationship of interdependence. Moreover, in terms of livability, New Taipei is rapidly improving, as can be seen from the most recent 
changes in the livability index. Several urban indices indicate that the urban development of New Taipei emphasizes enhancing public facilities, decreasing crime rates, improving public transportation, which implies a development direction toward rapid urbanization. One result of this is an unusual type of urban sprawl, which is shaping the structure of the capital region; however, the impact this will have on livability remains unclear. Because New Taipei already has a history of its own and is already home to numerous industrial parks, trading areas, and major cities, such as Banqiao and Yonghe, its developmental pattern is like that of a multi-center city. Moreover, its sizable rural area demonstrates that New Taipei is neither a suburb of Taipei nor a collection of satellite cities, despite its close relationship with Taipei.

To increase its rating in the livability index, New Taipei must make improvements in a number of areas, especially the number of western doctors, sewage disposal, educational level, garbage collection, crime rate, number of fires, per capita expenditures, household income, household expenditures, and disposable income.

The historical expansion of Taipei has been from west to east, and in recent decades the city commercial center has shifted even further east to the Xinyi Planning District, where real estate prices are on a par with those of large cities in industrialized nations. However, for livability, between 2007 and 2009, Taipei maintained its position as the most livable city in Taiwan. As a highly urbanized capital city, Taipei offers the greatest economic opportunities, but it is also the most expensive city in Taiwan. The most recent livability index shows that livability in Taipei is continuing to improve, as evidenced by decreasing crime rates and environmental problems, as well as lower levels of garbage production, car ownership, and electricity consumption. Although Taipei no longer requires huge expenditures for public construction projects, city policy makers continue to promote various measures to expand the city's financial and service industries and sponsor plans designed to enhance Taipei's international profile. Such measures provide numerous benefits to local residents and will ensure that Taipei maintains its position as the most livable city in Taiwan.

The most challenging problem the capital region will face in the near future is an aging population caused by a rapidly falling birth rate, an issue which has a bearing not only on urban development and livability, but also has major implications for national competitiveness. As development increases, birth rates decline, as is the case in all developed nations. A more immediate and particular reason for the declining birth rate in the capital region, however, is that the cost of housing in Taipei has recently increased dramatically, but a proportionate increase in income has not occurred, leaving residents in a difficult economic situation.
Consequently, faced with the choice of either accepting a lower standard of living or having fewer or no children, it is unsurprising that many people choose the second option.

\section{References}

1) Council for Economic Planning and Development (2008). Statistics on urban and regional development for 2006. Taipei: Council for Economic Planning and Development.

2) Dong Xiaofeng, et al. (2010). Method and Planning in Livable Cities. China Architecture and Building Press

3) Herbert, G. (2004). Cities people planet: Livable cities for a sustainable world. West Sussex: Wiley-Academy, 88.

4) Institute for Physical Planning \& Information (2010). Semi-annual report on residential demands, vol. VII, No. 2. Taipei: Construction and Planning Agency of the Ministry of the Interior of the R.O.C.

5) Ji J. C. (2006). Metropolitan and regional governance. Taipei: WuNan Publications.

6) National Science Council (2009). The Redevelopment plan for Chung Hsing New Village. Taipei: National Science Council.

7) Roberts, B. \& Kanaley, T. (Eds.) (2006). Urbanization and sustainability in Asia: Case studies of good practice. Washington, D.C.: Asian Development Bank.

8) Register, R. (1987). Ecocity Berkeley: Building cities for a healthy future. Berkeley: North Atlantic Books.

9) Sustainable Development Center of the Department of Land Economics at National Chengchi University (2000). An Urban Index System for Measuring the Sustainable Development of Taipei City: An Assessment Manual. Taipei: National Chengchi University.

10) Wang, R. S. (1988). The principles and methods of urban ecology: Efficiency and balance. Changsha, China: Hunan Education Press.

11) Wei-Yi Li and Chia-Chi Yao (2010). Development and Livability in Taiwan. ICEESD 2011: International Conference on Energy, Environment, Sustainable Development.

12) Wong, T. C., Yuen B., \& Goldblum, C. (2008). Spatial planning for a sustainable Singapore. Dordrecht, Holland: Springer Science.

13) Wu, M. S. (2008). Assessing the efficiency of major urban development in Taiwan. Ph.D. dissertation, National Cheng Kung University, Department of Urban Planning. (In Chinese.) http:// sedac.ciesin.columbia.edu/es/epi/

14) Zhang, W. Z., et al. (2006). Research on livable cities in China. Beijing: Social Sciences Academic Press. 